\title{
PENGARUH MEDIA PEMBELAJARAN KOMIK TERHADAP MINAT BELAJAR KIMIA SISWA PADA MATERI KOLOID DI KELAS XI MIA MAN 1 BANJARMASIN
}

\section{The Effect of Comic Learning Media Towards Students' Learning Interest in Chemistry on Colloid Topic at Class XI MIA MAN 1 Banjarmasin}

\author{
Marlinasari, Mohan Taufiq Mashuri, Gusti Hadiatus Solehah \\ Program Studi Pendidikan Kimia Fakultas Keguruan dan Ilmu Pendidikan \\ Universitas Islam Kalimantan (Uniska) Muhammad Arsyad Al Banjari, Banjarmasin \\ *e-mail: marlinsari@gmail.com
}

\begin{abstract}
Abstrak.Penelitian ini dilaksanakan di MAN 1 Banjarmasin dengan tujuan untuk mengetahui ada tidaknya pengaruh media pembelajaran komik terhadap minat belajar kimia siswa pada materi koloid. Penelitian ini merupakan penelitian eksperimen semu (quasi-experimental research). Populasi pada penelitian ini adalah seluruh siswa kelas XI MIA di MAN 1 Banjarmasin yang terdiri dari 3 kelas yaitu kelas XI MIA 1, XI MIA 2, dan XI MIA 3. Sampel dalam penelitian ini yaitu kelas XI MIA 1 (kelas eksperimen) dan kelas XI MIA 2 (kelas kontrol). Teknik pengumpulan data yang digunakan dalam penelitian ini adalah angket. Dari hasil analisis data dengan uji Independent Sample Test dapat diketahui $Z_{\text {hitung }}=$ 2.807 terletak diluar daerah penerimaan $\mathrm{H}_{0}(-1.96<\mathrm{Z}<1.96)$. Karena $\mathrm{Z}_{\text {hitung }}>1.96$ maka dapat disimpulkan bahwa ada pengaruh media pembelajaran komik terhadap minat belajar kimia siswa pada materi koloid, dengan $21.43 \%$ siswa kelas eksperimen tergolong memiliki minat belajar kimia yang tinggi sedangkan kelas kontrol sebesar $10.71 \%$. Untuk meningkatkan minat belajar kimia siswa, pembelajaran dengan menggunakan media komik dapat menjadi bahan pertimbangan oleh guru-guru kimia sebagai variasi dalam melaksanakan pembelajaran kimia.
\end{abstract}

Kata Kunci: Media Pembelajaran; Media Komik; Minat Belajar

\begin{abstract}
This research was conducted at MAN 1 Banjarmasin with the aim to know whether there is influence of comic learning media to student's chemistry learning interest in colloid material.This research is a quasi-experimental research. The population in this study is all students of class XI MIA in MAN 1 Banjarmasin consisting of 3 classes, XI MIA 1, XI MIA 2, and XI MIA 3. Samples in this research are class XI MIA 1 as experiment class and class XI MIA 2 as control class. Data collection techniques used in this study is a questionnaire. From the results of data analysis with the Independent Sample Test can be known that $Z_{\text {calculated }}=2.807$ is located outside the approval area $H_{0}(-1.96<Z<1.96)$. Because $Z_{\text {calculated }}>1.96$ then it can be concluded that there is influence of comic learning media to student's chemistry learning interest in colloid material, with $21.43 \%$ of experimental class students classified as having high chemistry learning interest while control class is $10.71 \%$. To increase students' chemistry learning interest, learning by using comic media can be considered by chemistry teachers as variations in chemistry learning.
\end{abstract}

Keywords: Learning Media, Comic Media, Learning Interest 


\section{PENDAHULUAN}

Proses pembelajaran khususnya kimia lebih efektif dan bermakna apabila siswa berpartisipasi aktif, dengan cara tidak menunjukkan sikap pasif di dalam kelas maupun di luar kelas. Untuk mengatasi masalah tersebut, guru harus berusaha untuk mengatasinya dengan mengkondisikan proses pembelajaran yang dapat mengaktifkan siswa. Untuk membuat kondisi pembelajaran lebih menarik dan materi yang disampaikan guru mudah dipahami siswa perlu adanya media pembelajaran. Pemanfaatan media dalam proses pembelajaran merupakan suatu perantara yang membawa pesan-pesan atau informasi yang bertujuan instruksional atau mengandung maksud-maksud pengajaran (Arsyad, 2007). Media pembelajaran dapat meningkatkan minat belajar siswa dan dapat merangsang siswa mengingat apa yang sudah dipelajari selain memberikan rangsangan belajar baru.

Salah satu media yang dapat digunakan untuk menarik perhatian siswa dalam proses belajar mengajar adalah media pembelajaran komik. Komik adalah suatu bentuk seni yang menggunakan gambar-gambar tidak bergerak yang disusun sedemikian rupa sehingga membentuk jalinan cerita. Biasanya, komik dicetak di atas kertas dan dilengkapi dengan teks. Kelebihan komik diantaranya: sifatnya konkrit, lebih realistik dibandingkan dengan media verbal; dapat memperjelas suatu masalah dalam bidang apa saja, baik untuk usia muda maupun tua; tidak memerlukan peralatan khusus dalam penyampaiannya; serta menjadi media yang menarik bagi yang membaca. Komik dapat diterbitkan dalam berbagai bentuk, mulai dari strip dalam koran, dimuat dalam majalah, hingga berbentuk buku tersendiri. Buku-buku komik dapat dipergunakan secara efektif oleh guru dalam usaha membangkitkan minat, mengembangkan perbendaharaan katakata dan keterampilan, membaca dan memperluas minat baca (Raini, 2011).

Penggunaan media pembelajaran komik ini dilatarbelakangi adanya faktor kesesuaian terhadap materi dan teori, adanya kesesuaian terhadap karakteristik siswa yang lebih tertarik dengan penggunaan media sebagai alat pembelajaran di kelas, serta adanya faktor kesesuaian gaya belajar, yang biasanya guru lebih sering menerapkan metode pembelajaran yang kurang menarik dan bervariasi.

Penelitian terdahulu yang mendukung penelitian ini adalah penelitian yang dilakukan oleh Novisilta (2016) yang menyatakan bahwa media komik terbukti meningkatkan minat belajar fisika siswa kelas VII SMP Katolik 2 W.R. Soepratman Barong Tongkok di Kutai Barat pada materi Konsep Zat. Hal ini ditunjukkan dengan rata-rata nilai kuisioner minat siswa sebesar 34 dengan persentase minat sebesar $93 \%$. Sehingga berdasarkan masalah dan hasil penelitian tersebut, maka penulis tertarik untuk melakukan penelitian yang berjudul "Pengaruh Media Pembelajaran Komik terhadap Minat Belajar Kimia Siswa pada Materi Koloid di Kelas XI MIA MAN 1 Banjarmasin“.

\section{METODE PENELITIAN}

Jenis penelitian ini adalah eksperimen semu (quasi eksperimental research) dengan desain penelitian yang berbentuk pretest-posttest control group design. Penelitian dilaksanakan di MAN 1 Banjarmasin mulai bulan April sampai Mei 2017.Populasi dari penelitian ini adalah seluruh kelas XI MIA sedangkan sampel penelitian yaitu kelas XI MIA 1 sebagai kelas eksperimen dan kelas XI MIA 2 sebagai kelas kontrol denga nmenggunakan teknik cluster sampling (Margono, 2004). Instrumen yang digunakan dalam penelitian ini yaitu silabus, rencana pelaksanaan pembelajaran 
(RPP) ,komik, dan angket. Sebelum instrumen-instrumen tersebut dapat digunakan dalam penelitian maka perlu diuji kelayakannya. Untuk silabus, RPP, dan komik dengan meminta judgement pada dosen atau orang yang dianggap ahli sedangkan untuk angket menggunakan rumus perhitungan uji validitas dan uji reliabilitas. Validasi dilakukan di kelas XI MIA 3. Uji validitas dihitung menggunakan rumus korelasi product moment yang dikemukakan oleh Pearson (Sujarweni \& Endrayanto, 2012) sedangkan uji reliabilitas menggunakan rumus cronbach alpha (Arikunto, 2006).Kemudian setelah data penelitian diperoleh, data perlu melalui uji persyarat yaitu uji normalitas dan ujihomogenitas. Uji normalitas menggunakan rumus Chi Square (Sujarweni \& Endrayanto, 2012) sedangkan uji homogenitas untuk dua kelompok data menggunakan rumus uji F (Irianto, 2009). Setelah melalui uji persyaratan, makadiuji hipotesis.Jika data normal dan homogen maka menggunakan uji bedadua rata-rata populasi (independent sample t-test).

\section{HASIL DAN PEMBAHASAN}

Hasil analisis uji validitas angket menggunakan rumus korelasi product moment dari 12 butir pernyataan diperoleh semua butir pernyataan valid, dengan kata lain angket dapat mengukur minat belajar siswa. Setelah dinyatakan valid, angket diuji reliabilitasnya menggunakan rumus cronbach alpha, hasil uji sebesar 0.929 tergolong memiliki tingkat keterandalan instrumen sangat tinggi, dengan kata lain angket dapatdipercaya untuk digunakan sebagai alat pengumpul data. Angket ini dibagikan pada siswa sebelum diberiperlakuan (pretest) dan sesudah diberi perlakuan (posttest) dimana kelas eksperimen menggunakan media pembelajaran komik sedangkan kelas kontrol tanpa menggunakan media pembelajaran.

Setelah didapatkan data pretest dan posttest maka data diuji normalitas dan homogenitasnya. Berdasarkan analisa data yang telah dilakukan, diperoleh hasil bahwa data berdistribusi normal dan homogen. Selanjutnya dilakukan uji-Z untuk menguji hipotesis. Hasil uji-Z yang dilakukan terhadap minat belajar siswa adalah sebesar 2.807 ( $Z_{\text {hitung }}$ ). Nilai $Z_{\text {hitung }}$ ini terletak diluar daerah penerimaan $\mathrm{H}_{0} \quad(-1.96<\mathrm{Z}<1.96)$. Berdasarkan kaidah pengambilan keputusan, dari hasil penelitian tersebut dapat disimpulkan bahwa $Z_{\text {hitung }}>1.96$, terletak di sebelah kanan batas penerimaan $\mathrm{H}_{0}$, sehingga hipotesis penelitian $\left(\mathrm{H}_{\mathrm{a}}\right)$ diterima, yaitu ada perbedaan minat belajar siswa setelah diberi perlakuan dengan menggunakan media komik, dengan kata lain media komik berpengaruh positif terhadap minat belajar kimia siswa.

Media komikdapat meningkatkan efekifitas proses pembelajaran, karena dengan gambar-gambar yang menarik dengan cerita yang kuat akan membuat siswa berkeinginan untuk membacanya (Kristanti \& dkk, 2015). Penggunaan komik sebagai media pembelajaran mempunyai peranan yang sangat penting, yakni memiliki kemampuan dalam menciptakan minat belajar siswa serta membantu siswa dalam mempermudah mengingat materipelajaran yang dipelajarinya(Mediawati, 2011).

Dari hasil penelitian ini menunjukkan bahwa media komik dapat menarik perhatian siswa, sehingga menimbulkan minat bagi diri siswa.Cerita bergambar dengan desain karakter dan warna yang menarik berisi materi koloid dalam media komik menimbulkan rasa penasaran bagi siswa, sehingga mereka senang untuk membaca dan mempelajarinya.Dengan menggunakan media komik tersebut, memudahkan mereka untuk belajar dan memahami materi kimia. 


\section{SIMPULAN}

Berdasarkan hasil dan analisa peneliti diperoleh kesimpulan bahwa penerapan media pembelajaran komik berpengaruh positif terhadap minat belajar kimia siswa kelas XI MIA MAN 1 Banjarmasin pada materi Koloid, dilihat dari hasil uji hipotesis yang menyatakan bahwa terdapat perbedaan yang signifikan minat belajar sebelum dan sesudah diberi perlakuan dengan minat belajar kelas eksperimen yang lebih tinggi dari kelas kontrol. Saran dari penelitiantara lain media komik dapat menjadi bahan pertimbanganoleh guru-guru kimia sebagai variasi dalam melaksanakan pembelajaran untuk menarik minat belajar siswa, dalam menerapkan media pembelajaran komik peneliti atau pengajar harus mengupayakan sistem kontrol yang lebih baik agar proses diskusi dapat berjalan dengan optimal, media komik dapat digunakan pada topik dan materi lainnya, serta media komik membutuhkan waktu yang cukup lama dan lumayan rumit dalam pembuatannya, sehingga lebih baik digunakan pada materi yang tidak membutuhkan banyak rumus dan persamaan.

\section{DAFTAR RUUJUKAN}

Arikunto, S. (2006). Prosedur Penelitian Suatu Pendekatan Praktik. Jakarta: Rineka Cipta.

Arsyad, A. (2007). Media Pembelajaran. Jakarta: Raja Grafindo Persada.

Irianto, A. (2009). Statistik Konsep Dasar dan Aplikasinya. Jakarta: Kencana.

Kristanti, \& dkk. (2015). Pengembangan Modul IPA Terpadu Tema Pemanasan Global Berbasis Komik di SMPN 4 Delanggu. Jurnal Inkuiri, 4(1), 117-221.

Margono. (2004). Metodologi Penelitian Pendidikan. Jakarta: Rineka Cipta.

Mediawati, E. (2011). Pembelajaran Akuntansi Keuangan Melalui Media Komik Untuk Meningkatkan Prestasi Mahasiswa. Universitas Pendidikan Indonesia, 12(1), -.

Novisilta, F. (2016). Penggunaan Media Komik untuk Meningkatkan Minat dan Hasil Belajar Fisika Siswa kelas VII SMP Katolik 2 W.R.Soepratman Barong Tongkok di Kutai Barat pada Materi Konsep Zat. Yogyakarta: Universitas Sanata Dharma.

Raini, Y. (2011). Peningkatan Aktivitas dan Hasil Belajar Kimia Siswa Menggunakan Media Grafis Komik-Kartun pada Pokok Bahasan Larutan Asam-Basa di Kelas XI IPA SMA Negeri 9 Kota Bengkulu. Kota Bengkulu: Universitas Bengkulu.

Sujarweni, W., \& Endrayanto, P. (2012). Statistika Untuk Penelitian. Yogyakarta: Graha Ilmu. 